\title{
PENINGKATAN HASIL BELAJAR PENDIDIKAN \\ KEWARGANEGARAAN MELALUI METODE PEMBELAJARAN CONTEXSTUAL AND LEARNING
}

\author{
Reza Rachmadtullah, Prayuningtyas Angger Wardani \\ Mahasiswa S3 Pascasarjana Universitas Negeri Jakarta \\ rezarachmadtullaheza@yahoo.com \\ ayuningtyaswardhani@yahoo.com
}

\begin{abstract}
Abstrack : The purpose of this study was to determine how the application of methods Contextual Learning And, to improve learning outcomes Civic Education about my hero. Research conducted at the Elementary School District 22 Mempawah Mempawah West Kalimantan, with research subjects fifth grade students totaling 30 people. This research is an action using a model Kemmis and McTaggart, conducted in two cycles. Each cycle consists of planning, implementing action, observation, and reflection action. The data collection process through tests mastery of learning outcomes Civics students, especially the material to understand the meaning and relevance of the symbols of the precepts of Pancasila in the understanding of Pancasila as a whole, and nontes be the observation of the implementation of the method of learning through methods Contexstual And Learning by using observation sheet activities of teachers and students, interviews, field notes, and documentation of results. The results showed an increase learning outcomes Citizenship Education about understanding the meaning and relevance of symbols in understanding the precepts of Pancasila Pancasila as a whole. This is evidenced by the value of learning outcomes Citizenship Education students about the hero in the first cycle is $50 \%$ of students who completed an average of 69 classes, were increased in the second cycle reaches $80 \%$ of students who completed, with an average grade 77 . Activities of teachers and students according to the steps of this method reach $100 \%$ at the end of the second cycle.
\end{abstract}

Keywords: Learning Outcomes, Contexstual Method And Learning, Civic Education

\begin{abstract}
Abstrack : Tujuan penelitian ini adalah untuk mengetahui cara penerapan metode Contexstual And Learning, untuk meningkatkan hasil belajar Pendidikan Kewarganegaraan tentang pahlawanku. Penelitian dilaksanakan di Sekolah Dasar 22 Mempawah Kabupaten Mempawah Kalimantan Barat, dengan subjek penelitian siswa kelas V yang berjumlah 30 orang. Penelitian ini merupakan penelitian tindakan dengan menggunakan model Kemmis dan McTaggart, dilakukan dalam dua siklus. Setiap siklus terdiri dari tahap perencanaan, implementasi tindakan, pengamatan, dan refleksi tindakan. Proses pengumpulan data melalui tes penguasaan hasil belajar Pendidikan Kewarganegaraan siswa khususnya materi memahami makna dan keterkaitan simbol-simbol sila pancasila dalam memahami pancasila secara utuh, dan nontes berupa hasil observasi pelaksanaan metode pembelajaran melalui metode Contexstual And Learning dengan menggunakan lembar pengamatan aktivitas guru dan siswa, wawancara, catatan lapangan, dan hasil dokumentasi. Hasil penelitian menunjukkan adanya peningkatan hasil belajar Pendidikan Kewarganegaraan tentang memahami makna dan keterkaitan simbol-simbol sila pancasila dalam memahami pancasila secara utuh. Hal ini dibuktikan dengan nilai hasil belajar Pendidikan Kewarganegaraan siswa tentang pahlawanku pada siklus I yaitu 50\% siswa yang tuntas dengan rata-rata kelas 69, meningkat pada siklus II mencapai $80 \%$ siswa yang tuntas, dengan rata-rata kelas 77 . Aktivitas guru dan siswa sesuai langkah-langkah metode ini mencapai $100 \%$ pada akhir siklus II.
\end{abstract}

Kata kunci: Hasil Belajar, Metode Contexstual And Learning, Pendidikan Kewarganegaraan 

Ada berbagai rumusan yang dikemukakan orang dalam upaya menjawab pertanyaan dengan melihat pendidikan dari salah satu aspek kehidupan tertentu atau kacamata disiplin keilmuan tertentu. Misalnya pandangan sosiologik melihat pendidikan dari aspek sosial bahwa pedidikan itu adalah sebagai usaha pemindahan pengetahuan dan nilai - nilai kepada generasi berikutnya. Sedangkan pandangan Psikologik melihat pendidikan dari aspek tingkah laku individu, antara lain mengartikan pendidikan sebagai perkembangan kapasitas individu secara optimal. Pandangan dari sudut ekonomi antara lain melihat bahwa pendidikan itu adalah sebagai usaha penanaman modal insan (Human Investmen), dan yang terakhir dilihat dari sudut pandang politik antara lain melihatnya sebagai pembinaan usaha kader bangsa.

Dari uraian diatas kita dapat menarik benang merahnya bahwa pendidikan itu adalah suatu kebutuhan yang akan menjamin kelangsungan hidup bagi setiap manusia. Hal ini telah terbukti dengan adanya proses dari pendidikan itu sendiri dimana pada masa sekarang ini, seseorang yang berpendidikan akan memegang peranan penting dalam setiap aspek kehidupan dalam masyarakat.
Untuk mendukung hal tersebut tentunya diperlukan metode-metode ataupun cara-cara yang akan membuat peserta didik mampu menyerap dan memahami materi apa yang akan kita sampaikan yang nantinya kapasitas kita tentu saja akan menjadi seorang pendidik. Selain dengan metode atau cara-cara yang efektif kita juga harus mampu memahami peserta didik secara personal maupun secara kelompok.

Dalam makalah yang akan kami paparkan kali ini yaitu menganai Prinsip Belajar dan Pembelajaran yang nantinya akan membantu seorang pendidik untuk lebih memahami dan lebih mengenal peserta didiknya

Pendidikan mempunyai peranan yang sangat penting untuk menjamin perkembangan dan kelangsungan hidup suatu bangsa. Karena kualitas kehidupan bangsa sangat ditentukan oleh faktor pendidikan. Oleh karena itu pembaharuan pendidikan harus selalu dilakukan untuk meningkatkan kualitas pendidikan nosional. Kemajuan sustu bangsa hanya dapat dicapai melalui penataan-penataan pendidikan yang baik. Upaya peningkatkan mutu pendidikan itu diharapkan dapat menaikan harkat dan martabat manusia indonesia. Oleh karena 
itu, maka pendidikan harus adaftif terhadap perubahan zaman.

Untuk memperbaiki mutu pendidikan yang ada sekarang ini salah satunya dalam mengembangkan potensi siswa untuk aktif, kreatif dan mandiri dalam proses pembelajaran sehingga tujuan pendidikan yang akan dicapai dapat tercapai dengan baik. Penyelenggaraan pendidikan tidak dapat dilepaskan dari tujuan pendidikan yang hendak dicapai berdasarkan pembangunan nasional, yang pada hakikatnya dilaksanakan oleh bangsa indonesia meliputi seluruh bidang kehidupan, salah satunya adalah bidang pendidikan yang diajarkan di sekolah yaitu bidang studi Pendidikan Kewarganegaraan

Peran mata pelajaran Pendidikan Kewarganegaraan di Sekolah Dasar bertujuan agar siswa mampu mengembangkan pengetahuan dan keterampilan yang berguna bagi siswa dalam kehidupan bermasyarakat, berbangsa dan bernegara. Dalam proses pembelajaran Pendidikan Kewarganegaraan diperlukan adanya keaktifan, supaya siswa mampu mengembangkan pola pemikiranya sehingga dapat berfikir kritis dan rasional sehingga hasil belajarnya pun akan berkembang kearah yang lebih baik. Mata pelajaran Pendidikan Kewarganegaraan tidak hanya menekankan pada aspek kognitif saja tetapi mencakup semua aspek yang bertujuan untuk mengembangkan potensi individu agar menjadi warga negara yang aktif dan partisipatif. Sedangkan untuk tujuan Pendidikan Kewarganegaraan di sekolah lebih ditekankan pada penguasaan pengetahuan dan keterampilan yang dapat memberikan bekal siswa dalam menghadapi kehidupan sehari-hari. Menurut Peraturan Menteri Pendidikan Nasional Nomor 22 Tahun 2006 tentang Standar Isi untuk Satuan Pendidikan Dasar dan Menengah adalah mata pelajaran yang memfokuskan pada pembentukan warga negara yang memahami dan mampu melaksanakan hak-hak dan kewajibannya untuk menjadi warga negara Indonesia yang cerdas, terampil, dan berkarakter yang diamanatkan oleh Pancasila dan UUD 1945.

Azis Wahab (2000:18) menyatakan bahwa Pendidikan Kewarganegaraan ialah media pengajaran yang meng-Indonesiakan para siswa secara sadar, cerdas, dan penuh tanggung jawab. Karena itu, program Pendidikan Kewarganegaraan memuat konsep-konsep umum ketatanegaraan, politik dan hukum negara, serta teori umum yang lain yang cocok dengan target tersebut. Dapat diartikan bahwa Melalui 
Pendidikan Kewarganegaraan, siswa dan warga negara Republik Indonesia seluruhnya diharapkan mampu "memahami, menganalisa, dan menjawab masalahmasalah yang dihadapi oleh masyarakat, bangsa dan negaranya secara konsisten dan berkesinambungan dengan cita-cita dan tujuan nasional seperti yang digariskan dalam Pembukaan Undang-Undang Tahun 1945.

Minto Rahayu (2009:17) bertujuan membekali dan memantapkan dengan pengetahuan dan kemampuan dasar hubungan warga negara Indonesia yang pancasila dengan negara dan sesama warga negara dengan kemampuan dasar diharapkan mampu menerapkan nilai-nilai pancasila dalam kehidupan sehari-hari, memiliki kepribadian yang mantap,berpikir kritis, bersikap rasional, esistensi dan dinamis, berpandangan luas, bersikap demokrasi dan berkeadaban.

Dapat diartikan bahwa Pendidikan Kewarganegaraan di Indonesia dapat diharapkan mempersiapkan peserta didik menjadi warga negara yang memiliki komitmen yang kuat dan konsisten untuk mempertahankan Negara Kesatuan Republik Indonesia. Hakikat negara kesatuan republik indonesia adalah negara kesatuan modern. Negara kebangsaan adalah negara yang pembentuknya didasarkan pada pembentukan semangat kebangsaan dan nasionalisme yaitu pada tekad suatu masyarakat untuk membangun masa depan bersama di bawah satu negara yang sama. Walaupun warga masyarakaat itu berbeda-beda agama, ras, etnik, atau golongannya Pendidikan.

Kenyatannya di lapangan, dari data yang didapat nilai rata-rata untuk mata pelajaran Pendidikan Kewarganegaraan kelas $\mathrm{V}$ semester gasal yaitu 58,2 dengan batas ketuntasan minimalnya (KKM) yaitu 75. Berdasarkan data tersebut peserta didik yang mampu mencapai nilai $\geq 75$ hanya sebesar $40 \%$, sedangkan sisanya memperoleh nilai di bawah batas ketuntasan minimal.

Data di atas peneliti dapatkan setelah melakukan wawancara dengan pendidik kelas V di SD tersebut. Rendahnya prestasi belajar peserta didik tersebut antara lain disebabkan oleh faktor dari pendidik dan peserta didik. Agar hasil belajar pada mata pelajaran Pendidikan Kewarganegaraan dapat meningkat dari data sebelumnya, pendidik harus memberikan inovasi dalam proses pembelajaran. Salah satu cara yang dapat ditempuh berkaitan dengan inovasi tugas mengajar adalah pendidik hendaknya mempunyai kemampuan dalam 
Peningkatan Hasil Belajar Pendidikan

Kewarganegaraan Melalui Metode Pembelajaran

Contexstual And Learning

Reza rachmadtullah, Prayuningtyas A.W

mengembangkan metode mengajar. Metode pembelajaran adalah cara-cara menyajikan materi pelajaran yang dilakukan oleh pendidik agar terjadi proses belajar pada diri peserta didik dalam upaya untuk mencapai tujuan (Sobri Sutrisno, 2014). Khususnya dalam hal ini adalah metode untuk menunjang proses pembelajaran pada mata pelajaran Pendidikan Kewarganegaraan. Pemilihan metode pembelajaran juga perlu diperhatikan karena tidak semua materi dapat diajarkan dengan hanya satu metode pembelajaran. Pendidik hendaknya dapat memilih metode pembelajaran yang dianggap sesuai dengan materi yang hendak diajarkan. Hal ini dimaksudkan agar pengajaran Pendidikan Kewarganegaraan dapat berlangsung secara efektif, efisien, dan tidak membosankan.

Dalam penelitian ini peneliti menggunakan metode Contextual Teaching and Learning atau yang selanjutnya disebut Contextula Teaching And Laearning merupakan suatu proses pendidikan yang holistik dan bertujuan memotivasi siswa untuk memahami makna materi pelajaran yang dipelajarinya dengan mengaitkan materi tersebut dengan konteks kehidupan mereka sehari-hari sehingga siswa memiliki pengetahuan/keterampilan yang secara fleksibel dapat diterapkan (ditransfer) dari satu permasalahan/konteks ke permasalahan/konteks lainnya.

Menurut Johnson (2002:5) tentang contextula teaching and laearning sebagai berikut: Contextual teaching and learning is a system of instruction based on the philosophy that students learn when they see meaning in academic material, and they see meaning in school-work when they can connect new information with prior knowledge and their own experience

Dapat diartikan bahwa Contextula Teaching And Laearning merupakan sistem pengajaran berdasarkan filosofi bahwa siswa belajar ketika mereka melihat makna dari materi akademik, dan mereka melihat makna dari pekerjaan sekolah ketika mereka bisa menghubungkan informasi baru dengan informasi atau pengetahuan yang sudah ada dan merupakan pengalaman siswa itu sendiri.

Menurut Elaine B. Johnson (2002:25) dalam Contextula Teaching And Laearning, minimal ada 3 (tiga) prinsip utama yang sering digunakan, yaitu sebagai berikut; (1) prinsip saling ketergantungan (interdepence); (2) prinsip perbedaan; dan (3) pengorganisasian diri (self organization). Secara khusus dapat dijelaskan dari ketiga prinsip tersebut bahwa (1) prinsip saling ketergantungan 
dimaksudkan di sini bahwa pembelajaran kontekstual merupakan pembelajaran yang menekankan hubungan antara bahan pelajaran dengan bahan lainnya, antara teori dan praktik, antara bahan yang bersifat konsep dengan penerapan dalam kehidupan nyata. (2) Prinsip perbedaan, mendorong peserta didik menghasilkan keberagaman perbedaan dan keunikan melalui berpikir kritis dan kreatif. (3) pengorganisasian diri, proses pembelajaran diatur, dipertahankan, dan disadari oleh peserta didik sendiri, dalam rangka merealisasikan seluruh potensinya. "The contextual teaching and learning system consists of eight components: making connections that hold meaning, self-regulated learning, doing significant work, collaboration, critical and creative thinking, nurturing the individual, reaching high standards, and using authentic assessment".

Proses pembelajaran kontekstual memiliki 8 (delapan) komponen yakni

(1)melakukan hubungan yang bermakna; (2) mengerjakan pekerjaan yang berarti; (3) mengatur cara belajar mandiri; (4) bekerja sama;(5) berpikir kritis dan kreatif; (6) mengasuh atau memelihara pribadi siswa; (7) mencapai standar yang tinggi; dan (8) menggunakan penilaian yang autentik (sebenarnya).

\section{METODE}

Penelitian ini merupakan penelitian tindakan kelas (classroom action research). Desain intervensi tindakan/rancangan siklus dalam penelitian ini menggunakan model Kemmis dan Mc.Taggart, dengan menggunakan sistem spiral yang dimulai dari perencanaan (planning), tindakan (acting), pengamatan (observing), refleksi (reflecting), dan dilanjutkan lagi ke perencanaan kembali (replanning) sebagai dasar untuk strategi pemecahan masalah.

Penelitian tindakan ini dilakukan melalui dua siklus, yang disesuaikan dengan kondisi dan hasil refleksi ketercapaian peningkatan yang diharapkan pada siklus sebelumnya, sesuai dengan tindakan yang dilakukan. Pada siklus pertama belum berhasil, maka dilanjutkan pada siklus berikutnya.

Pada tahap perencanaan tindakan yang meliputi perencanaan umum dan perencanaan khusus. Perencanaan umum meliputi perencanaan waktu pelaksanaan penelitian yang akan dilakukan selama kurang lebih dua bulan. Peneliti mengadakan pertemuan dengan kepala sekolah untuk konsultasi, dan pertemuan dengan rekan sejawat peneliti untuk mendiskusikan langkah-langkah 
pelaksanaan penelitian. Selain itu direncanakan pengaturan kondisi kelas, persiapan materi pelajaran serta media/alat pembelajaran yang diperlukan, pembuatan kisi-kisi instrumen observasi tindakan, dan kisi-kisi instrumen hasil belajar siswa tentang pahlawanku.

\section{Adapun perencanaan khusus} disesuaikan dengan jadwal pembelajaran dan disusun dalam tiap pelaksanaan tindakan. Dalam hal ini peneliti membuat rencana pembelajaran sesuai Kurikulum yang berlaku, menyiapkan media pembelajaran yang diperlukan pada setiap pelaksanaan tindakan, menyiapkan lembar observasi tindakan dan instrumen evaluasi hasil belajar siswa tentang pahlawanku, serta pengumpulan data lainnya berkaitan dengan penelitian ini.

Tahapan pelaksanaan tindakan merupakan realisasi tindakan pada dasarnya disesuaikan dengan setting tindakan yang telah ditetapkan dalam rencana pelaksanaan pembelajaran (RPP). Tindakan dilaksanakan sejalan dengan langkahlangkah metode pembelajaran Contextula Teaching And Laearning yang telah direncanakan, untuk meningkatkan hasil belajar siswa tentang pahlawanku.
Penelitian tindakan ini dilaksanakan dalam dua siklus, masing-masing siklus dilakukan 2 kali tindakan dengan alokasi waktu 1 kali tindakan adalah 2 × 35 menit sesuai dengan program pembelajaran.

Instrumen pengumpulan data yang digunakan sebagai bahan penilaian terhadap kegiatan proses dan hasil belajar siswa adalah menggunakan instrumen pengumpulan data yang telah dipersiapkan, seperti tes hasil belajar Pendidikan Kewarganegaraan dan berupa lembar observasi/pengamatan ketika menjalankan metode Contextula Teaching And Laearning Oleh sebab itu teknik penilaian yang digunakan disesuaikan dengan objek yang dinilai dan disesuaikan dengan tujuan penilaian. Untuk menilai aktivitas proses dan hasil belajar siswa, teknik penilaian yang dipergunakan adalah dengan mengumpulkan data dengan menggunakan tes hasil belajar berupa tes soal uraian serta lembar penilaian berupa lembar observasi/pengamatan.

Kegiatan observasi (observing) dilakukan bersamaan dengan pelaksanaan tindakan yang bertujuan untuk mengenali, merekam dan mendokumentasikan proses pembelajaran yang terjadi, berkenaan 
dengan kegiatan guru dan siswa selama tindakan dilakukan. Observer mengamati pelaksanaan kegiatan pembelajaran dengan menggunakan lembar observasi aktivitas guru dan siswa, sambil merekam atau mendokumentasikannya. Hasil rekaman dan dokumentasi penting dilakukan agar data yang diperlukan dalam penelitian ini dapat dijaring secara lengkap dan akurat. Selain itu peneliti mencatat semua peristiwa atau hal yang terjadi di kelas selama proses pembelajaran berlangsung.

Tahapan refleksi tindakan merupakan upaya mengkaji secara menyeluruh tindakan yang telah dilakukan, berdasarkan data yang telah terkumpul, kemudian melakukan evaluasi untuk menyempurnakan tindakan berikutnya. Tahapan ini yang dilakukan oleh peneliti dan kolaborator setelah pelaksanaan tindakan. Kegiatan refleksi dilakukan secara kolaboratif, dengan mendiskusikan hasil analisis lembar observasi, catatan lapangan, serta faktor penyebab permasalahan lainnya yang terjadi selama pembelajaran di kelas. Hasil refleksi ini menjadi acuan revisi untuk menentukan perencanaan kembali (replanning) pada siklus berikutnya.
Peneliti dan kolaborator mengevaluasi kekurangan atau kelemahan serta kemajuan-kemajuan yang diperoleh guru dan siswa. Selain itu dalam kegiatan refleksi, dilakukan juga perbandingan antara hasil belajar siswa tentang tema pahlawanku, sebelum dan sesudah diberikan tindakan. Apabila belum terjadi peningkatan hasil belajar siswa, maka penelitian dilanjutkan pada siklus berikutnya. Setelah beberapa siklus dilakukan dan telah terjadi peningkatan hasil belajar, tentang tema pahlawanku sesuai dengan kriteria yang akan dicapai, maka peneliti dapat mengakhiri penelitian.

Selanjutnya pada siklus berikutnya dilaksanakan berdasarkan analisis data hasil observasi, pemaknaan data hasil observasi, penjelasan hasil analisis dan kesimpulan mengenai presentase teratasi atau tidaknya permasalahan dalam pembelajaran, serta faktor-faktor lainnya yang menjadi petimbangan belum tercapainya target dalam penelitian ini.

\section{HASIL \\ Dilihat dari hasil analisis data selama tindakan mulai siklus I sampai siklus II terlihat adanya peningkatan dari semua data}


Peningkatan Hasil Belajar Pendidikan

Kewarganegaraan Melalui Metode Pembelajaran

Contexstual And Learning

Reza rachmadtullah, Prayuningtyas A.W

yang diambil. Data tes berupa skor dalam memahami makna dan keterkaitan simbolsimbol sila pancasila dalam memahami pancasila secara utuh melalui metode Contextula Teaching And Laearning mangalami peningkatan, dan hasil analisisnya dapat dilihat pada perkembangan hasil yang dicapai mulai dari siklus I meliputi data hasil observasi yang diperoleh dari lembar observasi tindakan guru dan siswa.

Hasil pada siklus I pertemuan pertama lembar observasi guru dalam pembelajaran Contextula Teaching And Laearning mencapai 33,33\% dan kemudian menjadi 44,44\%. Hasil pada siklus I pertemuan pertama lembar observasi siswa dalam pembelajaran Contextula Teaching And Laearning mencapai 44,44\% dan kemudian menjadi 76,92\%. Peningkatan ini menunjukkan bahwa metode Contextula Teaching And Laearning yang diterapkan pada proses pembelajaran ini dapat membuat perubahan yang cukup bagi keberhasilan guru dalam proses pembelajarannya.

Selanjutnya pada hasil instrumen tes siklus I dengan presentase ketuntasan belajar adalah 50\%, memahami makna dan keterkaitan simbol-simbol sila pancasila dalam memahami pancasila secara utuh melalui metode Contextula Teaching And Laearning yaitu 6 siswa mendapat nilai 5059 (20\%), 9 siswa mendapat nilai 60-69 (30\%), 9 siswa mendapat nilai 70-79 $(30 \%), 5$ siswa mendapat nilai 80-89 $(16,67 \%), 1$ siswa mendapat nilai 90-100 $(3,33 \%)$.

\section{PEMBAHASAN}

Meningkatkan kemampuan memahami makna dan keterkaitan simbolsimbol sila pancasila dalam memahami pancasila secara utuh melalui metode Contextula Teaching And Laearning, maka siswa dilatih untuk lebih aktif dan menghayati pemeranannya dalam permainan Contextula Teaching And Laearning. Selain siswa dilatih untuk berdiskusi dengan kelompoknya dan bekerja sama untuk saling memperbaiki pemeranannya dalam permainan tersebut. Pada tindakan siklus I ini siswa belum terbiasa bermain peran dalam berdiskusi dengan teman lainnya dengan satu kelompok sehingga mereka kelihatannya masih bingung. Dengan demikian hasil dari proses pembelajaran dan hasil tes pada 
siklus I ini masih jauh dari target yang diharapkan pada penelitian ini.

Selanjutnya pada siklus II, siswa diberikan motivasi dalam meningkatkan pemeranannya dalam permainan Contextula Teaching And Laearning dan memberikan latihan yang maksimal terhadap kelompok masing-masing pemeran. Setiap kelompok di berikan motivasi hadiah berupa buku bacaan dan alat-alat tulis bagi kelompok yang tampil lebih bagus dari siklus sebelumnya yakni siklus I. Dengan adanya pemberian hadiah ini siswa berlombalomba untuk tampil lebih bagus dan penuh semangat. Dengan demikian hasil yang diperoleh pada siklus II meningkat.

Hasil pada siklus II pertemuan pertama lembar observasi guru dalam pembelajaran Contextula Teaching And Laearning mencapai 66,66\% dan kemudian menjadi 100\%. Hasil pada siklus II pertemuan pertama lembar observasi siswa dalam pembelajaran Contextula Teaching And Laearning mencapai 66,66\% dan kemudian menjadi $100 \%$. Peningkatan ini menunjukkan bahwa metode Contextula Teaching And Laearning yang diterapkan pada proses pembelajaran ini dapat membuat perubahan yang cukup bagi keberhasilan guru dalam proses pembelajarannya.

Selanjutnya pada hasil instrumen tes siklus II dengan presentase ketuntasan $80 \%$, memahami makna dan keterkaitan simbolsimbol sila pancasila dalam memahami pancasila secara utuh melalui metode Contextula Teaching And Laearning yaitu 3 siswa mendapat nilai 50-59 (10\%), 3 siswa mendapat nilai 60-69 (10\%), 6 siswa mendapat nilai 70-79 (20\%), 15 siswa mendapat nilai 80-89 (50\%), 1 siswa mendapat nilai 90-100 (33,33\%).

Dengan demikian hasil yang telah meningkat secara signifikan pada siklus II ini sebagaimana harapan peneliti telah tercapai, maka penelitian ini tidak dilanjutkan lagi karena telah mencapai hasil yang diharapkan. Namun terdapat 6 siswa tidak tuntas karena mencapai nilai yang dicapai pada siklus II di bawah KKM.

\section{SIMPULAN}

Berdasarkan hasil penelitian tindakan tentang peningkatan hasil belajar Pendidikan Kewarganegaraan melalui metode Contextula Teaching And Laearning pada siklus I dan siklus II menghasilkan kesimpulan bahwa 
Peningkatan Hasil Belajar Pendidikan

Kewarganegaraan Melalui Metode Pembelajaran

Contexstual And Learning

Reza rachmadtullah, Prayuningtyas A.W

Pembelajaran Contextula Teaching And

Laearning dapat meningkatkan kegairahan siswa dalam pembelajaran sehingga mengurangi kejenuhan siswa dalam menerima pelajaran. Dalam pembelajaran perlu diberikan reward atas penghargaan kepada siswa yang berhasil sebagai motivasi bagi siswa lainnya untuk meningkatkan hasil belajar yang dikehendaki. Hasil belajar siswa dari siklus I dan siklus II meningkat secara signifikan dengan KKM 70. Hasil siklus I dari 30 siswa hanya 15 orang yang dinyatakan lulus, dengan rata-rata kelas 69 presentase 50\%. Kemudian perbaikan pembelajaran metode CONTEXTULA TEACHING AND LAEARNING dilanjutkan pada siklus II dengan rata-rata kelas 77 presentase $80 \%$ mengalami peningkatan dari siklus I. Dari jumlah 30 orang hanya 6 orang siswa yang tidak tuntas

\section{DAFTAR RUJUKAN}

Abdul Aziz Wahab,(2002) Teori dan Landasan Pendidikan dan Kewarganegaraan .Bandung: Alfabeta

Aisah, Siti. 2010. Pola Integrasi Nilai-nilai Pendidikan Keluarga dalam
Pembelajaran Pendidikan

Kewarganegaraan dan Habituasi di

Sekolah Dasar Untuk Membangun

Karakter Siswa (Studi Kasus Pada

Madrasah Tsanawiyah Negeri

Sawahgede Cianjur). Bandung:

Universitas Pendidikan Indonesia.

Arbayta, Alvyta Layla.2015 Pengaruh Model Pembelajaran Kooperatif Tipe Numbered Head Together (NHT) Terhadap Hasil Belajar PKn Siswa Kelas V SD Negeri 1 Klegung 1 Tempel. Yogyakarta: Universitas Negeri Yogyakarta.

Friedman, S. Howard. 2008. Kepribadian Teori Klasik dan Riset Modern Edisi Ketiga Jilid 1. Jakarta: ErlanggA.

Johnson, (2002). Contextual Teaching and Learning: What It Is and Why It's Here to Stay .USA: Sage Publications Ltd.

M.Sobry Sutikno, (20014) Metode\& Model-Model Pembelajaran .Lombok.

McCoach, D. Besty, Robert K. Gable, dan John P.Madura, 2013. Instrument Development in the Affective Domain: School and Corporate Aplication $3^{\text {rd }}$ Edition. New York: Springer. 
JURNAL PENDIDIKAN DASAR

Volume 7 Edisi 1 Mei 2016

Minto Rahayu, (2009). Pendidikan Kewarganegaraan "Perjuangan Menghidupi Jati Diri Bangsa” Jakarta: Grasindo,2009

Peraturan Menteri Pendidikan Nasional Nomor 22 Tahun 2006 tentang Standar Isi untuk Satuan Pendidikan Dasar dan Menengah.
RahayuMinto.2009.PKn Perjuangan Menghidupi Jati Diri Bangsa .Jakarta: Grasindo.

Winarko, Jarot. 2010. Multiple Intelligences Anak Cerdas, Ceria, Berakhlak. Banten: PT. Happy Holy Kids 